\title{
THE ROLE AND CONTRIBUTION OF THE PHANARIOT RULERS WITHIN THE ACADEMY OF BUCHAREST
}

\author{
Năstase (Gheorghe) Mihaela \\ Ms. PhD,"Valahia" University of Târgoviște, Romania, mihaela.gheorghe25@gmail.com
}

\begin{abstract}
The Ruler School from Saint Sava Monastery, transformed into an Academy by the Phanariot ruler Alexander Ypsilanti in 1775, represented the first form of higher education in Wallachia. With a multitude of professors trained in Constantinople and Padua, the Academy grouped a significant number of students. The disciples came from the ranks of the boyars, but also students from outside the borders, who came to study. The sons of merchants had the right to follow the elementary cycle of study, then engaged in the practice of a trade.

From the year of foundation, 1679 and until 1821, the school went through numerous reforms. The ones on which I stopped more carefully are those belonging to Rulers Constantin Brâncoveanu and Alexander Ypsilanti. Some of the students benefited from scholarships, food and clothing. The program was very strict and well organized.

The age at which children could come to school was seven years. Most of the time was devoted to joint or individual study, neither prayer nor physical exercises were neglected.

Saint Sava was the favourable environment for the development of science-based education, the place of scholastic being increasingly restricted. In the syllabus here the philosophical disciplines, the positive sciences and the modern languages have found their place, which is why many of the professors from Constantinople have taught in Wallachia.
\end{abstract}

Keywords: Saint Sava Royal Academy, school, education, teachers, students, Phanariot rulers.

\section{INTRODUCTION}

During the Medieval times, the school was regarded as a cultural instrument that functioned at the beginning near churches and monasteries (Gheorghe Pârnuță, 1971, p. 100; Claudiu Neagoe, 2015, vol. II, pp. 454455). At the end of the seventeenth century and the beginning of the eighteenth century, the foundations of higher education were established in Wallachia and Moldova, through the two ruler schools of Saint Sava in Bucharest (Wallachia) and the one of the Three Hierarchs in lasi (Moldova). The installation of the Phanariot rulers represented on the one hand the completion of the Orientalizing process of the Romanian culture from the south and east of the Carpathians (Cl. Neagoe, M. Toma, 2018, p. 191), and on the other hand it determined the development of education, the increase of the number of public and private schools, the emergence of libraries.

At the time of the introduction of higher education in Wallachia by Constantin Brâncoveanu, more precisely 
at the end of the seventeenth century, the teaching was done in Greek or Latin. The spread of Greek language and culture was the main vector of Orthodoxy in South-East Europe. Greek was considered more appropriate as a language of instruction in the major university centres compared to Latin.

Attempts to establish and organize higher education have existed in Wallachia since the first half of the seventeenth century, during the reign of Leon Tomşa, when a certain Benedict, Cretan monk and preacher of the Royal Court (Nicolae lorga, 1928, p. 285), had the initiative to establish a higher school probably in Greek in Bucharest (Ariadna Camariano-Cioran, 1971, p. 21).

In the eighteenth century, a significant number of boyars employed Greek and later French teachers (Nicolae Stoicescu, 2017, p. 184) for the education of their offspring, while merchants saw the use of Romanian as much more useful. Two of the sons of the seneschal Constantin Cantacuzino, Drăghici and Serban (Victor Brătulescu, 1963, p. 860) had as a teacher the Greek Paisie Ligaridis (Ariadna Camariano-Cioran, 1971, p. 9). The erudite steward Constantin Cantacuzino had as a teacher first a certain Dionysius, then Gherasim Vlahos from Crete (Ariadna Camariano-Cioran, 1971, p. 21). Before the Phanariot period, even during the time of Matei Basarab, we met at the time a significant number of Romanian youths sent to study abroad: Ștefan of Paulului from Câmpulung and Ștefan Valahul studied at the college in Rome (Gheorghe Pârnuță, 1971, p. 76). In Venice were studying Pascale's son, the Vornic of Târgoviște, lordache and Mateiaș, the sons of Matei Crețulescu were studying in the West (Cristian Luca, 2007, p. 100). In the Brancovenian era, the ruler sent Greek scholars to Venice. Among them the most famous are: Gheorghe Chrysogon Hypomenas, a doctor who came from Trapezunt, Anton Stratigos, Paladie Damian (Nicolae lorga, 1928, p. 16). Therefore, the schools in Wallachia enjoyed internal and external appreciation.

\section{THE BEGINNING OF THE RULER SCHOOL FROM SAINT SAVA MONASTERY}

In 1679, Serban Cantacuzino established the school of Saint Sava within the monastic complex of the Saint Sava monastery: „among the first things, Șerban Vodă Cantacuzino created the Greek school, which was preserved by the following rulers, who decided to give them (the teachers) also an annual salary from the Treasury "(Constantin Erbiceanu, 2003, p. XIII).

The church of Saint Sava was erected by Andronache Pârcălabul before 1600 (Constantin V Obedeanu, 1900 , p. 984). It was dedicated to the Saint Sava of Jerusalem, which is why it remained in the collective mind with the name of the Saint Sava Monastery. Both Brâncoveanu and his predecessor, Șerban Cantacuzino, have shown a special interest for this school. He had significant funds, because the church of Saint Sava had estates in Ghergani, in Tâmburești, stores at the fair in the city, at Târgul de Sus and in the Sfânta Vineri Suburb in Bucharest (Constantin V Obedeanu, 1900, p. 984). It was renewed from the foundation, in 1709, the administrator of the works being Radu Dudescu lord steward (George D. Florescu, 1935, p. 53). During the time of Serban Cantacuzino, important progress was made in the field of construction, but also in the cultural field. Constantin C. Giurescu mentioned the "honourably paid" teachers (Constantin C. Giurescu, 2009, p. 179) by this ruler, to teach in the ancient Greek language - the language of the high sciences - the sons of boyars.

Using the analysis realized by lon lonașcu regarding the prints from the time of Șerban Cantacuzino and those belonging to Constantin Brâncoveanu, it turns out that, in the prefaces of Grammarians from Snagov from 1697, Greek and Arabic liturgical book (Snagov, 1697) thanks were made to Ruler Constantin Brâncoveanu for his care for schools. Also, in Confession of the Orthodox faith, the Greek edition of Snagov 1699, Sevastos Kymenites signed an epigram entitled "the professor of sciences of the Royal School in Bucharest" (Ion Ionașcu, 1964, p. 17). This signature shows that, in 1699, in Bucharest there was this royal school.

Also, Nicolae lorga mentioned the Royal Academy of Saint Sava in Bucharest, led by Sevastos the Kymenites from Trapezunt, as the dream of the steward Constantin Cantacuzino, a dream come true on the ascension of his brother, Șerban (1678). The teaching language was Greek and it was a school dedicated to the sons of boyars, led by the prince, lordache (Gheorghe), the son of Vodă and a daughter of a merchant from Bulgaria known in Wallachia under the name of Ghetea (Nicolae lorga, 1928, p. 20). Another student who linked his name to the school in Bucharest was the uncle of that lordache, Matei Crețulescu (Ibidem, p. 21). In 1694, Brâncoveanu reorganized, within the cells of Saint Sava Monastery in Bucharest, a school in the Greek language, later known as the Royal Academy (Ion lonașcu, 1964, p. 122).

Ariadna Camariano-Cioran affirmed that, due to the importance he gave to the Royal Academy in Bucharest with teaching in Greek, the purpose of the ruler was to transform it into an inter-Balkan cultural centre around which the struggle of the Orthodox people against Turks would rise (Ariadna Camariano- Cioran, 1971, pp. 19-20). 
De facto, a large part of the organization and the curriculum applied in the school of Saint Sava were taken from the Academy of Padua, where the steward Constantin Cantacuzino also studied (Ion Ionașcu, 1964, p. 19).

There is no doubt today that the founding of the Bucharest higher school was carried out under the strict ruling and supervision of the steward Constantin Cantacuzino, having as an example the curriculum in Padua where he studied (Ibidem, p. 20).

\subsection{The Teachers from Saint Sava}

At the head of this high institution of culture was placed the erudite scholar, Sevastos Kymenites (Constantin Obedeanu, 1900, p. 990). Native of Trapezunt, a disciple of Alexandru Mavrocordat along with Spandonache (Chesarie Daponte, 1900, p.17), the future professor in Constantinople, he was passionate about Eortologios for holidays and the theory of orthodoxy, classical literature, in particular, Isocrates, Synesius, Agapett and Theophilact (Nicolae lorga, 1921, p. 23). He managed the school from Saint Sava until he died in 1702. He had come to Wallachia in 1684, at the call of Șerban Cantacuzino, who named him tutor of his son, Gheorghe. After the Ruler's death, Kymenites returned to Constantinople. He came back to Bucharest, this time definitively, in 1689. He died on the lands of Wallachia, being buried at the Saint Sava monastery (Stefan Ionescu, Panait I Panait, 1969, pp. 319-320). This is how Constantin Daponte described him in Historical catalogue of the important men of the eighteenth century, most of whom lived in the Romanian Countries Wallachia and Moldova: "The great Brâncoveanu, who loved him so much for his great teaching and put him above all the boyars, honour that another ruler did not give another teacher and do not give" (Chesarie Daponte, 1900, p. 203). After the disappearance of Kymenites, education in Bucharest registered a decrease (Ariadna Camariano-Cioran, 1971, p. 29), which causes Brâncoveanu to take reorganization measures. The documents of reorganization on modern principles were made in close collaboration with the Patriarch Hrisant Notara, whom he asked to establish the school syllabus with the studied subjects. In the charter, Brâncoveanu also indicates the amount of money that was received by each teacher: the philosophy teacher being the principal of the school was paid with Lei 200, and the second with Lei 100 (Ibidem, p. 34). To ensure a constant income for the school, Brâncoveanu deposited at the bank of Venice Thalers 30,000, and their interest amounting to Thalers 819 was used for the welfare of the school. By another charter, the ruler decides that the Greek customs will be granted Lei 50 annually, an amount used exclusively for foreign students and those without means (Eudoxiu de Hurmuzaki, part II, 1917, pp. 427-428). The document was written in Târgoviște, on 9 September 1707 by Mihai, the son of Stan logofăt Târgovișteanul.

Through his charter, Constantin Brâncoveanu reorganized the higher education to which children from the country but also foreigners had access. The 50 Thalers from Greaca were used for their food. The caretaker and the administrator of the school was named the hegumen of Saint Gheorghe monastery (Elena Grigoriu, 1978, pp. 20-21).

After the disappearance of Kymenites, two other great Greek scholars followed the leadership of the Royal Academy: Manuel (Mark) Porphyropulos from Cyprus and Gheorghe Hypomenos from Trapezunt (Stefan Ștefănescu, 1996, p. 124). Mark Porphyropulos, also known as Marcu Cipriu, held the position of director, but he was also known as the character who refused to print the three volumes from Chrysostom's work, because they are heretical. As a result of his refusal, he was cursed as an incidental overlap, he dies of cancer (Constantin Erbiceanu, 2003, p. 204).

The activity of Hypomenos is closely related to the collaboration with the Greek from the Levant, Nicolae da Porta, a high Austrian official in Oltenia, the translator of Ștefan Cantacuzino and a collaborator in organizing the library in Mărgineni (Nicolae lorga, 1971, p. 23).

Other teachers who activated in the beginning period were: Ioan Comnen, named in monasticism lerotheu, the future metropolitan of Distria (Constantin Erbiceanu, 2003, pp. XXVI). He was a professor of mathematical and physical sciences between 1680 and 1700. Until the year of his death (1719) he collaborated with Antim Ivireanul in editing various Greek writings; Gheorghe Maiota, a Latin language professor between 1690-1710, the tutor of Constantin Brâncoveanu's sons for Latin and Greek (Constantin Erbiceanu, 2003, p. XXVI). He was followed by Panaghiot Sinopues, the student of Sevastos Kymenites, professor (1697-1710) and proofreader for books that appeared in Greek during this period; then Gheorghie Trapezundiul also named Ipomeneus with studies of medicine and philosophy at the University of Patavia. He died in Bucharest in 1745. The list of professors was completed by Mitrofan Grigoraș, mentioned in 1705 at Saint Sava (Ariadna Camariano - Cioran, 1971, p. 56) and George Hrisogon from Trapezunt, the nephew of Sevastos Kymenites and the successor of Mark, professor of philosophy. He composed various eulogies The Birth of the Lord and the Resurrection spoken by students in front of the Lord (Constantin Erbiceanu, 2003, p. XXVII). He was also the author of canons and hymns for the Holy Haralambie, whose head was 
brought in times of plague to obtain forgiveness from the deity; Ioan Avramiu, a professor in 1716 and translator of the work The legislation of some of the ancient philosophers, printed at Târgoviște (1713) (Ibidem, p. XVIII).

During the period 1714-1775 there taught as teachers: Alexander Turnavitu, professor of philosophy, died in 1761, being buried at St. Sava. He studied at the college in Târnovo (Olga Cicanci, 1984, vol. II, p. 36) and he was the mentor of the one who will become the professor, Manase Eliade (Constantin Erbiceanu, 2003, p. XXVI); Lazăr Scriba, director of Bucharest Academy in 1735, the doctor in philosophy and medicine (Ibidem, p. XXVII). His most important work was the History of Romanians, used as a teaching manual, starting from the works of the Romanian chroniclers. It was quite common for the method used by the teachers of the time to create the textbooks that they used in the department. After 1750, carried out the teaching activity Manase Eliade (lliade Manasi), a native of Melenic of Macedonia. His studies in Bucharest were continued in Patavia and Bononia, and as a professor we meet him between 1759-1785 (Elena Grigoriu, 1978, p. 57). He was the one to whom Alexander Ypsilanti entrusted the task to go to Italy and Germany to buy the tools needed to equip the laboratory and for conducting scientific experiments in the school (Ștefan lonescu, 1974, p. 79).

In 1778 was known the name of professor Anastasie, to whom the work The Life of Ruler Necolai Peter Mavroghene was attributed, printed in Bucharest at the printing house Cişmea, in 1789 (Constantin Erbiceanu, 2003, p. LXIX). He was followed by Dimitrie Pamber Procopio, a native of Ohrida or Moschopol (Chesarie Daponte, 2003, p. 224), Constantin Mavrocordat's professor, a graduate from medicine and philology, secretary of state during the ruling of Nicolae Mavrocordat. He knew the Greek and Latin languages. Another notable name from Saint Sava was Necolai Varcosi, a professor at the academy and tutor for the sons of Constantin Moruzi.

Towards the end of the eighteenth century, the courses were supported by the following professors: losif Mesiodax, a native of Cernavodă, proficient in Greek, Latin, French, Italian and Romanian; Costanda the hieromonk; Filipid Daniel collaborated with Costanda in the creation of a geography manual; Alexander, professor of philosophy; Sava Anastasie, Dimitrie Chidone, Lambru Dimar, professor and director in Bucharest, Chesarie, Bishop of Râmnic, student of Alexander Turnautu; Gheorghie of Arghirocastru, professor around 1780, loanichie the hieromonk, Gheorghie Popa, son of loan Siastin, professor in Bucharest you know, Neofit Cavsocalivitul, a native of ludei, director in 1788. He wrote the paper in Romanian entitled Prastia; Grigorie Costanda succeeded to the management of the Academy to Neofit Cavsocalivitul. Then followed scholar Lambros Fotiadis, who spoke Greek, Latin, French, Italian, German and Turkish, and he managed the academy in 1795 (Constantin Erbiceanu, 2003, p. XXIX) and Constantin Vardalah, professor of mathematics and philosophy. Vardalah was at the head of the Academy until 1815 when he left for Chios.

The prestige of the Royal Schools from Saint Sava and Saint Gheorghe Vechi in Bucharest exceeded the borders of the Romanian Countries. Saint Sava was the favourable environment for the development of science-based education, the place of scholasticism being increasingly restricted. In this syllabus were found the philosophical subjects, the positive sciences and the modern languages, which is why many of the professors from Constantinople went to Wallachia.

Papacostea called the city of Bucharest the intellectual centre of the Balkan world and the Near East (Victor Papacostea, 1961, p. 117). His study includes the two documents attesting the presence in the schools on the Romanian territory of the two Russian scholars. The document of 7 February 1705 issued by the Russian Chancellery at the command of Tsar Peter the Great and at the request of David Ceaușul, the representative of Wallachia in Moscow contained the Tsar's order to send to Bucharest for studies Andrei Mihailov. He was "the Greek translator of the Department of Foreign Affairs" (Ibidem, Annex no. 1, p. 116) and was sent to studies in Bucharest to learn Latin and other sciences. The document provided that the payment of the expenses for the study trip would be borne by the budget of the Department, about 200 Rubbles (Ibidem, pp. 120-121). The reference to the study of the other sciences could not be made anywhere better than to the royal school from the Saint Sava monastery, where he could hear courses of: Physics, About the sky, The birth and destruction of the world, About the soul, etc.

The second document attesting the presence of another Russian youth in the schools in Bucharest was 26 May 1707. He showed that, two years ago, in 1705, Danilo Vasilev, "student of the school of mathematical sciences and navigation" was sent to studies in Bucharest. The order was signed by Admiral Apraxin, the head of the Admiralty Department and Baron Safirov (Ibidem, p. 116). Danilo Vasilev was sent to studies to learn the Romanian language (Ibidem, Annex II, p.121). 


\title{
2.2 The Syllabus of the Ruler School
}

Patriarchal Grammata of August 1707 (Eudoxiu de Hurmuzaki, 1915, part I, doc. CCCCXXVI, pp. 392-394), which included The order of the teachers from Saint Sava presented the teaching methods, the forms of training and education, the content of the syllabus. The grammata outlined the teacher's profile: "Teachers should be three, distinguished by the kindness and good manners and morals", included also their attributions: the first teaches in a very strict form the following subjects: logics, rhetoric, physics, about heaven, about birth and death, about the soul, metaphysics. The second teacher teaches: The speeches of Isocrates, Sophocles and Euripides with their tragedies, The speeches of Grigore de Nazianz, The speech about the kingdom, and the Letters of Synesius, The Pindar's Songs, The speeches of Demosthenes, The Syntax of Alexander Mavrocordat, Xenophon, Plutarch, Thucydides. The third teacher teaches The thoughts of Hrysolora, Cato, The Rhetoric of Meletie, Fochilidis, Pythagoras, The myths of Aesop, The praises of Agapet, Simokates and Homer's work. He also taught Lascaris' grammar (Eudoxiu de Hurmuzaki, part I, 1915, pp. 392-394).

The students went through the following education cycles: first they studied with the third teacher, then the training continued with the second one. Only after this thorough preparation, they could study with the first teacher.

In 1714, Ștefan Cantacuzino gives a new charter for reorganizing the academy under the guidance of Hrisant Notara (Ibidem, p. 542). Because the activity was frequently interrupted, either because of wars or because of the lack of money for the payment of teachers, quite often reorganization was needed. At the urging of the patriarch, the Metropolitan of Wallachia, Mitrofan, he reopened the school closed during the Austro-Turkish war. In August 1715, the professor Porphyropulos, the director of the Royal School in Bucharest sends him a letter (Fig. 1, B.A.R. doc. ist. DCLXXXVI) to the Patriarch Hrisant Notara, in which he describes the evolution of the school at that time: three grammar sciences are taught except the grammar itself, subjects are taught in technology, physics is taught in philosophical sciences, and once or twice a week there were presented themes to the grammar of Alexander Mavrocordat (B.A.R., ms. gr. 355).

\begin{abstract}
...apologetic because of those defamations (translator's note: the sycophants) who came up against him or offered enough or strange information about the students and the teachers or the lessons in his school.

To the Most Blessed, His Holiness and the Wisest and Master, [I send him] my submissive worship and (...) along with the kiss of the righteous saint.

By the voice of His Holiness Archimandrite, the ruler Malachios, and the messenger of this letter, while respectfully and also on the knees I have confirmed the blessed wishes of your parental blessings and favours due in larger numbers (...)
\end{abstract}

(...) and the plot. The Cypriot Georgios reads Cato; learns writing (translator's note: He is taught) by the ruler Konstantinos Malatios, your servant, who in the Lord has hopes with your Holiness. He also takes care of his work. When he will start writing and spelling, he wants to have the letters dictated; the books offered (translator's note: dedicated) by him can be found at Saint Gheorghios until the comment after Easter is corrected.

At his excellence the master (translator's note: Archon, sovereign) doctor lancobov I personally bow down and I ask him, if it is his disposition, when he comes to worship him to say it; I again, by completing the work, bow down myself in front of your Holiness that the Lord has entrusted to celebrate with great glory and in the face of the resurrection of the all-loving master with all the spiritual joy and embrace: and this in many intervals (...) annually. Illegible signature

Fig. 1 The letter of Markos Porfyropoulos from Cyprus to Chrysanthos

The post-Brancovenian period was quite difficult for instruction and education in Wallachia. There are not many charters of the period between 1714-1741 regarding the regulation of the life of the Royal Academy in Bucharest or other schools in Wallachia.

The one that draws our attention is Mihai Racoviță through his charter from 1741, which attests the presence of the three teachers at the royal school: a teacher for philosophy, one for grammar and one for studying Italian (Elena Grigoriu, 1978, p. 54). From the same charter we find out that in Bucharest there was another teacher for Greek at the Church of All Saints and two teachers at the Slavonic school. There are also maintained the scholarships for 12 disciples "ordained for the priesthood" (Ibidem, p. 54). Mihai Racoviță also, at the urging and with the support of the boyars, gave the charter by which the condition is laid that the 
sons of the boyars who want to occupy a position and be elevated in rank must attend the higher courses (ANIC, Fond Diplomatice, inv. 77, doc. 20).

The Greek language had difficulties in establishing itself in the Wallachian society in the eighteenth century. In the first reign, Constantin Mavrocordat gave on 9 May 1746 a charter signed by the majority of the boyars, claiming the introduction of the condition of having solid knowledge to enter the hierarchy and to hold a position at the Royal Court (George Potra, 1982, doc. 143, p. 178).

After about three years, in the second reign of Grigore Ghica II (1748-1752), the charter for strengthening the two schools in Bucharest, the Greek and the Slavonic ones was issued, and the payment of the teachers was passed from the royal care, from the treasury of the state to the care of the metropolitan (at that time, Neofit). The salaries were also established: the first teacher, the one for teaching philosophy: 45 Thalers/month, the one for grammar 20 Thalers/month. If we analyse the Report, dated 1 September 1741, regarding the payment of teachers in Bucharest and other towns, we observe a favourable situation for the teacher of philosophy:

- 30 Thalers/month for the philosophy teacher from Saint Sava;

- 15 Thalers spent on his food;

- 20 Thalers/month for each grammar teacher; 5 Thalers for food;

- 400/year for 12 disciples ordained for the priesthood;

- 15 Thalers/month for the Italian teacher;

- 5 Thalers for his food;

- 10 Thalers/month for the two Slavonic teachers;

- 5 Thalers/month for the Greek teacher from the Church of All Saints;

- 10 Thalers/month for the teacher from Focșani for Greek;

- 5 Thalers/month for the Slavonic teacher from Buzău;

- 3 Thalers/month for Slavonic teacher in Râmnic;

- 3 Thalers/month for the Slavonic teacher in Târgoviște;

- 10 Thalers/month for the Greek teacher at Craiova school;

- 3 Thalers/month for Slavonic teacher from Câmpulung;

- 3 Thalers/month for the Slavonic teacher from Slatina school.

The charter was given by Grigore Ghica II of 1749, however, did not mention anything about the interest of the money deposited in Venice by Constantin Brâncoveanu and which was used for the welfare of the Royal Academy. The two teachers here (Alexander and Teodor) complained that they were receiving salaries with great delay, every 6 months from the Metropolitan Church.

In 1752, a new charter, prepared by priest Florea, a teacher at Saint George and signed by Matei Ghica, strengthened the privileges granted by Grigore Ghica II to the two schools in Bucharest and it is shown that their gates were open to both children in Wallachia, as well as for foreigners. On 23 October1752, Matei Ghica renews his father's charter according to which the teachers of the Greek and Slavonic schools are under the supervision of the metropolitan, and the payment of salaries enters into the duties of priests (ANIC, Fond Eforia Școalelor, inv. 24, pachet XVI, doc. 1).

The successor of Matei Ghica, Constantin Racoviță, in 1753, strengthened the charter regarding the payment of the teachers and decided that they should remain at the same value (ANIC, Fond Eforia Școalelor, inv. 24, pachet XVI, doc. 2).

In the second stage of the existence of the royal school, the most extensive reforms were made during Constantin Mavrocordat and Alexander Ypsilanti. The first issued a charter in 1758 (ANIC, Fond Eforia Școalelor, inv. 24, pachet XVI, doc. 4) through which the estate of the Glavacioc monastery was transferred to the patrimony of the royal school. He exempted the monastery from any duties for its estates, to facilitate the payment of the teachers and the maintenance of the disciples. The same measure is maintained by Constantin Mihai Cehan Racoviță, in 1763, by the charter of June 26 (ANIC, Fond Diplomatice, inv. 77, doc. 34) and included the following amounts for salaries: the first teacher 40 Thalers/month, the second teacher 
30 Thalers/month, the third teacher from Saint Sava Thalers/month; for the two teachers from St. George (Gheorghe) 15, respectively 10 Thalers/month. As an additional measure, Constantin Racoviță passed the revenues of the Glavacioc monastery, Domnița Bălașa and the Church of the Royal Court under the authority of the Metropolitan (Ioan Mușețeanu, 1933, doc. X, pp. 64-65) to ensure the payment of the teachers and the necessary to the schools from Saint Sava and Saint George. He also exempted these monasteries from paying the duties.

To increase the space for students, it was ordered to move the hegumen and monks from Saint Sava to Văcărești. Constantin Mavrocordat also decided that the assets of the deceased without heirs and without wills that came into the possession of the ruler, should enter the Metropolitan management with the precise purpose to be used for schools, hospitals, bridges (ANIC, Fond Eforia Școalelor, inv. 24, pachet XVI, doc. 3). In 1765, Ștefan Racoviță passed into the patrimony of the schools from Saint Sava and Saint George the revenues of the Dealu monastery as a solution for the timely payment of the teachers' salaries. To improve the situation of the schools, the next ruler of Wallachia Alexander Ghica, appointed a commission made up of the Metropolitan of Wallachia, the great vornic Racoviță, the great head of the army and the great logothete with attributions in the inspection of the schools and taking measures for their improvement (Elena Grigoriu, 1978, p. 57). On 5 October 1767, he ordered them to investigate in detail how the teachers from Saint Sava do their duty and to notify him. For the diligent and poor students to give them a sum of money for food and two Thalers per month, these being passed on to the expense report (ANIC, Fond Eforia S,coalelor, inv. 24, Pachet XVI, doc. 6).

Athanasie Ipsilant Comnen, former Protospatarian in Wallachia in 1765 (Constantin Erbiceanu, 2003, pp.

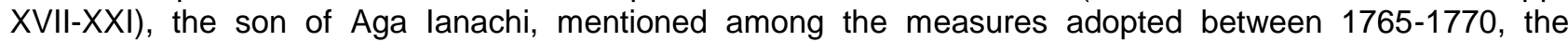
increase of the teachers' salaries and the establishment of the amount for the food given to the poor pupils amounting to twenty money bags. During this period, the school in Bucharest had insufficient money, with the payment of two teachers, one for grammar and one for science. That's why it was made the decision to take care of it, multiplying "by ceasing looking for another source".

The reorganization of education since 1774 during the reign of Alexander Ypsilanti no longer included the provision by which the monastery's revenues were used for the maintenance of schools. In support of these assertions, the request of the boyars of Wallachia to the ruler was formulated, to reintroduce the income of the Glavacioc monastery for the support of the schools (Ioan Mușețeanu, 1933, pp. 21). It seems that their request was appreciated by the ruler. Alexander Ypsilanti is forced to give a new reorganization and to increase the number of teachers from Saint Sava from two to nine (Nicolae Bănescu, 1925, p. 5): two for teaching grammar, two for mathematics, arithmetic, geometry, astronomy and history; one for teaching physics, one for teaching theology and three teachers for teaching foreign languages: Latin, French, Italian. At enthronement, Alexander Ypsilanti asked the Metropolitan to submit a complete report on the Greek and Slavonic schools in Bucharest. The report had to contain data on: the number of students of boyars and the other poorer students enrolled in school, the teachers of the school, their salaries and the source from which they are paid, the subjects taught, the number of classes and the students in a class (Nicolae lorga, 1971, p. 56). Although the answer received, unfortunately, was not kept, it seems that it was not a satisfactory one because Alexander Ypsilanti began a comprehensive program of reform in education.

Following the not at all favourable situation, presented by the Metropolitan of Wallachia regarding the situation at Saint Sava and Saint George (George Potra, 1982, doc. 216, pp. 252-254), the ruler gave the charter of 17 March 1775 (Eudoxiu de Hurmuzaki, part II, 1917, doc. MCCLXXIV, pp. 1270-1274; George Potra, 1982, doc. 216, pp. 252-254), by which it raises the royal school to the rank of the academy where are taught grammar, logics, rhetoric, philosophy, mathematics, French, Slavonic, Romanian. The same charter spoke about the establishment of elementary schools in Craiova, in the Diocese of Râmnic and that of Buzău, the studies being continued in Bucharest. It was desired to set up schools in each bourg town (county residence) with teachers of Romanian and Slavonic. From the beginning of the seventeenth century, at Râmnic royal school we find teacher Sîrbu and teacher Neniță.

Regarding the date of the transformation of the school from Saint Sava into the academy, there are several opinions: the year 1694, either 1695 or even 1707 (Gheorghe Pârnuță, 1971, p. 113) during Constantin Brâncoveanu's time. It is certain that the term of the academy is present in the charter of the Phanariot ruler Ypsilanti. On 10 December 1775, Ypsilanti undertakes an administrative reorganization, perhaps the largest until then, establishing the institution of the Vestry (V.A. Urechia, 1892, p. 38). It consisted of eight boyars with a chancellery of seven logothetes and one of its objectives was the good functioning of the schools. $\mathrm{He}$ determined that the Metropolitan together with the bishops of the country and the great boyars from the big ban to the big treasurer would decide the amount that each monastery had to give, making the difference between the worshipped and those of the country. The monasteries in the country had to pay the sum of 
9575 Thalers for school help, and the worshipped paid a smaller amount, considering that they also had other obligations (George, Potra, 1982, p. 52).

At the beginning of January 1776, it also appears the public charter of the schools in Greek. V.A. Urechia assumes that this charter was written by Alexander Ypsilanti himself, who did not master the Romanian language well. He assigned to Diocese the task of starting the work at the new premises for the school of Saint Sava. The buildings were only ready in 1779 and included "the refectory, the kitchen and the bakery" (V.A. Urechia, 1892, p. 52). It was desired to transform the school in Bucharest according to European standards so that the children of the boyars would no longer have to go to study in Europe. St. Sava's school was of a high character. There were used as teaching languages the Italian, Latin, French: "And the physics shall be taught in Greek, following Aristotle and his disciples, and those of mathematics, if they do not happen to master properly the Greek language, to teach also in Latin or French, and in Italian, where they will be stronger" (Eudoxiu de Hurmuzaki, 1917, doc. MCCXXIV, p. 1272).

Another measure taken by Ypsilanti was that concerning the specialization of teachers. There were 60 students with scholarships in five classes. They were provided with accommodation, meals and uniforms twice a year. Each class was supervised by a pedagogue, "a good-natured, modest man, to be used in the supervision of all movements and deeds" (ANIC, Fond Diplomatice, inv. 77, doc. 61). Those who had access to the boarding school were the sons of the boyars with a less favourable financial situation, craftsmen, merchants. The students signed a contract that obliged them to attend all courses, except for the sons of merchants and tradesmen who had the option that, after attending the elementary school, they could be exempted from attending school to choose a job (Eudoxiu de Hurmuzaki, 1917, doc. MCCLXXIV, pp. 12701274). The last provisions of the charter referred to the budget allocated to the Academy and the sources from which it came. There was talk of a budget of about Lei 15 250: 6000 from the non-worshiped monasteries, 4000 from the worshipped ones and 5250 the contribution of the priests (Ariadna CamarianoCioran, 1971, p. 42) A revenue and expenditure account was maintained. Paradoxically, coming out from the influence of the Church, with a strong secular character, the Academy was financially supported by the clergy. The charter was written and reinforced by the grammata of Patriarch Sofronie (Fig. 2), the Archbishop of Constantinople, Rome and ecumenical patriarch, accompanied by the curse addressed to those who will violate the royal commandment. It was written in the book by vel logothete, signed along with Sofronie, Abram, the Archbishop of Jerusalem and Palestine, Meletie of Ephesus, Parthenie of Chalcedon, and written by Constantine the Slavonic scholar from the royal school of Saint George.
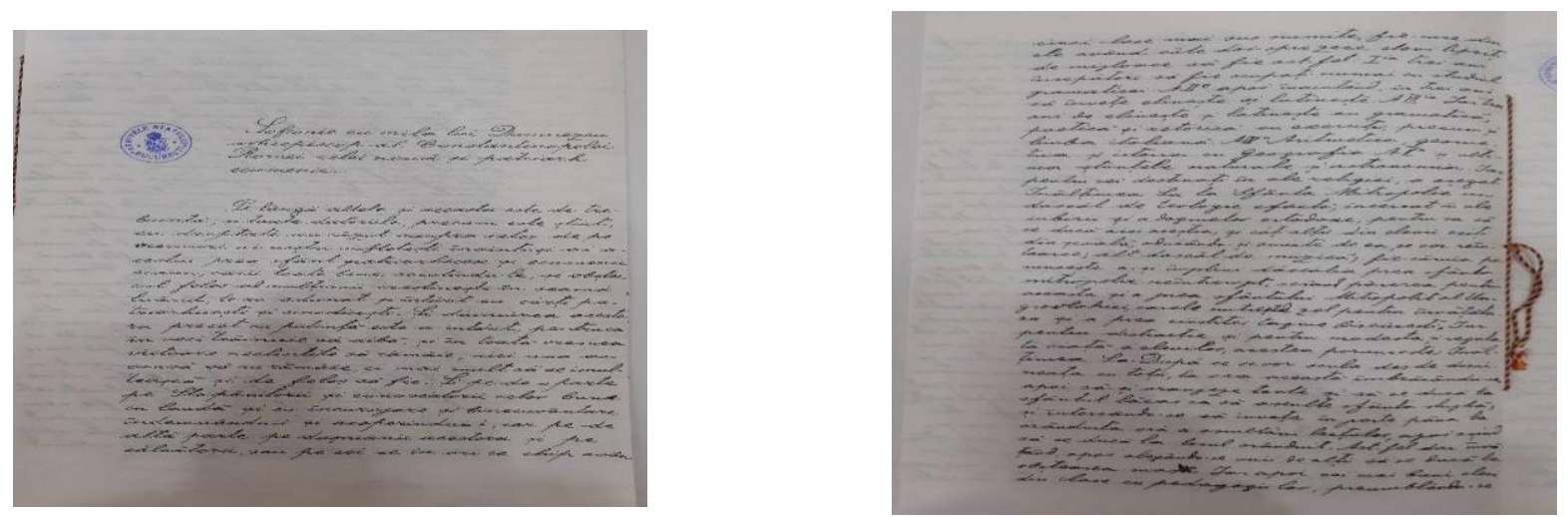

Fig. 2 Grammata of Patriarch Sofronie

What Ypsilanti did in this endeavour was to exclude the children of peasants from the scholarship, but that does not mean their exclusion from attending the academy courses. He imposed the obligation to attend courses until graduation, especially for scholars. Through the same charter, he also reorganized the library by appointing a librarian to help the students.

Following the "reform" of Ypsilanti, the Academy was subject to other reforms, all by improving the education. Thus, on 25 August 1786, the ruler Nicolae Mavrogheni appointed in the position of Nazir, that is to say, the school's caretaker, to the bishop of Râmni, Filaret. At the same time, he replied to the students from Saint Sava, who expressed their dissatisfaction that the State has no obligation towards them, but all that is offered to them is through the mercy and goodwill of the ruling;... for that reason, being satisfied with the mercy of what is ordered, be diligent in learning to show the results, because the dissatisfied, being brought to us by his holiness, we will miss him and we will chase him away "(V.A. Urechia, 1898, p. 77). Filaret was known as an important representative of Romanian culture. 
Attached to the name of Nicolae Mavrogheni, two other measures regarding education are worth mentioning: the first concerns the initiative to set up a school in the "Romanian seraglio" in Constantinople, where seven young people were to be sent to learn the Turkish language. The ruler commissioned Enache Văcărescu vel ban to choose the seven young people from the sons of great boyars and three-four of the boyars of the second rank or orphans. The young people had to have a minimum knowledge of Greek grammar (V.A. Urechia, 1892, p.78). The second concerns the vocational education that takes shape in for teacher Mihalache from the music class, 15 Thalers for three school children (V. A. Urechia, 1898, p. 80). Through the decree of 14 March 1787, Nicolae Mavrogheni appointed Nițu chief of the royal trumpeters, "to instruct and teach the craft" (V. A. Urechia, 1892, p. 79).

The unfavourable political context at the end of the eighteenth century led to the stagnation of the Academy's activity. Mihail Șuțu found the school with no doors, windows, stoves, beds and commissioned Vasile logofăt, the ruler of the royal court, to take care of everything needed to build including a shed and a small stable. After the peace of Şiștov (1791), the new ruler organized his royal court in the building of the school of Saint Sava, the school being moved to Domnita Bălașa. On this occasion, the inventory of the library was made and its relocation to Saint George (Ariadna Camariano-Cioran, 1971, p. 45). The inventory of books from the library was made by the care of the epitropic boyars and it was the responsibility of the science teacher. Although the schools were not fully reopened after the war, there were collections made at school normally. The decree to the two bishops of 22 July 1792 and the one to the Metropolitan Church of 17 August 1792 (V. A. Urechia, 1892, p. 120) confirmed this. The activity of the school was held at Domniţa Bălașa until 1803, when because of the earthquake the building collapsed, then it was moved to the Măgureanu metoh by the Metropolitan Dositei Filitti.

\section{CONCLUSION}

At the beginning of the nineteenth century, at the head of the Bucharest Academy were teachers Neofit Ducas and Commita. Following the tragic attack on Professor Neofit Ducas, caused by the expelled Greek student, from Zakynthos, we find out that the number of pupils enrolled was 400 : " 400 students, losing their father and teacher, do not know how to ease their pain, and their parents call the Furies "(V. A. Urechia, 1898, p. 120).

The last three decades of the eighteenth century have brought about major cultural changes. The French language was spreading more and more in the Romanian countries. The secretaries were proficient in French, the boyars were looking for French language teachers for their offspring.

\section{ACKNOWLEDGEMENT}

This work is supported by project POCU 125040, entitled "Development of the tertiary university education to support the economic growth - PROGRESSIO", co-financed by the European Social Fund under the Human Capital Operational Program 2014-2020.

\section{REFERENCE LIST}

Arhivele Naționale Istorice Centrale (ANIC), Fond Diplomatice, inv. 77, doc. 20, doc. 34.

ANIC, Fond Eforia Școalelor, inv. 24, pachet XVI, doc. 1, doc. 3, doc. 4, doc. 6.

Biblioteca Academiei Române (B.A.R), ms.gr. 355; B.A.R, doc. ist., DCLXXXVI.

Bănescu, Nicolae, (1925), Academia grecească din București și școala lui Gheorghe Lazăr. Contribuție la istoria învățământului românesc. Extras din „Anuarul Universității” pe 1923-1924, Institutul de Arte grafice „Ardealul”, Cluj.

Camariano-Cioran, Adriana, (1971), Academiile domnești din București și lași, Editura Academiei, București.

Daponte, Chesarie, (2003), Catalogul istoric a domnilor însemnați din secolul XVIII, dintre carii marea majoritate au trait în Țările române Valahia și Moldova în Constantin Erbiceanu, Cronicari greci care au scris despre români în epoca fanariotă, Editura Cronicar, București.

Idem, (2003), Cronicul de la 1648-1704 în Constantin Erbiceanu, Cronicari greci care au scris despre români în epoca fanariotă, Editura Cronicar, București. 
Hurmuzaki, Eudoxiu de, (1915, 1917), Documente grecești privitoare la istoria românilor publicate după originale. Copiile Academiei Române și tipărituri, partea I (1320-1716) și partea a II-a (1716-1777), Librăriile Socec., București.

Ionașcu, Ion,(1964), Cu privire la data întemeierii Academiei Domnești de la Sfântul Sava din București în „Studii”, tomul 17, nr. 6.

Idem,(1964), Activitatea de început a Academiei domnești de la Sfântul Sava (1694-1716) în „Analele Universității București. Seria Științe sociale- Istorie”, an. XIII.

Ionescu, Ștefan, Panait I., Panait, (1969), Constantin vodă Brâncoveanu, Editura Științifică, București.

lorga, Nicolae (1971), Istoria învățământului românesc, Editura Didactică și Pedagogică, București.

lorga, Nicolae (1928), Istoria românilor prin călători, vol. I, Editura Casa Școalelor, București.

Luca, Cristian, (2007), Țările Române și Veneția în secolul al XVII-lea, Editura Enciclopedică, București.

Mușețeanu, Ioan, (1933), Mânăstirea Glavacioc. Monografie istorică, Editura Cărților Bisericești, București.

Neagoe, Claudiu, (2015), O scurtă istorie a românilor. Secolele XV-XVII, vol. II, Editura Ars Docendi, București.

Neagoe, Claudiu, Toma, Marin, (2018), Tările Române în epoca fanariotă, Editura Ars Docendi, Bucureşti.

Papacostea, Victor, (1961), Doi bursieri al lui Petru cel Mare la școlile din București în „Studii. Revista de istorie", anul XIV, nr. 1.

Pârnuță, Gheorghe (1971), Istoria învățământului și gândirea pedagogică din Țările Române. Secolele XVIIXIX, Editura Didactică și Pedagogică, București.

Potra, George,(1982), Documente privitoare la istoria orașului București (1634-1800), Editura Academiei, București.

Stoicescu, Nicolae, (2017), Repertoriul bibliografic al monumentelor feudale din București, Editura Basilica, București.

Urechia, V. A., (1898), Istoria românilor, 1800-1821. Curs făcut la facultatea de Litere din Bucuresci, după documente inedite, tom III, Tipografia și fonderia de Litere Thoma Basilescu, București.

Urechia, V. A., (1892), Istoria școlelor, tomul I, Imprimeria statului, București. 